\title{
The importance of different spatial scales in determining structural and functional characteristics of deep-sea infauna communities
}

\author{
J. Ingels ${ }^{1,2}$ and A. Vanreusel ${ }^{1}$ \\ ${ }^{1}$ Section Marine Biology, Department Biology, Ghent University, Krijgslaan 281 S8 (WE11), 9000 Gent, Belgium \\ ${ }^{2}$ Plymouth Marine Laboratory, Prospect Place, West Hoe, Plymouth, PL1 3DH, UK
}

Correspondence to: J. Ingels (jingels13@gmail.com, jein@pml.ac.uk)

Received: 22 October 2012 - Published in Biogeosciences Discuss.: 7 January 2013

Revised: 3 May 2013 - Accepted: 8 May 2013 - Published: 5 July 2013

\begin{abstract}
The urge to understand spatial distributions of species and communities and their causative processes has continuously instigated the development and testing of conceptual models in spatial ecology. For the deep sea, there is evidence that structural and functional characteristics of benthic communities are regulated by a multitude of biotic and environmental processes that act in concert on different spatial scales, but the spatial patterns are poorly understood compared to those for terrestrial ecosystems. Deep-sea studies generally focus on very limited scale ranges, thereby impairing our understanding of which spatial scales and associated processes are most important in driving structural and functional diversity of communities. Here, we used an extensive integrated dataset of free-living nematodes from deep-sea sediments to unravel the importance of different spatial scales in determining benthic infauna communities. Multiple-factor multivariate permutational analyses were performed on different sets of community descriptors (structure, structural and functional diversity, standing stock). The different spatial scales investigated cover two margins in the northeast Atlantic, several submarine canyons/channel/slope areas, a bathymetrical range of 700-4300 m, different sampling locations at each station, and vertical sediment profiles. The results indicated that the most important spatial scale for structural and functional diversity and standing stock variability is the smallest one; infauna communities changed substantially more with differences between sediment depth layers than with differences associated to larger geographical or bathymetrical scales. Community structure differences were greatest between stations at both margins. Important regulating ecosystem processes and the scale on which they occur are discussed. The results imply that, if we are to improve our
\end{abstract}

understanding of ecosystem patterns of deep-sea infauna and the relevant processes driving their structure, structural and functional diversity, and standing stock, we must pay particular attention to the small-scale heterogeneity or patchiness and the causative mechanisms acting on that scale.

\section{Introduction}

The great variability in abundance, composition, structure and diversity displayed by natural communities have continuously instigated ecologists to develop and test conceptual models that explain patterns at various temporal and spatial scales based on biological interactions and/or abiotic processes (e.g. Connell, 1978; Hubbell, 2001; Levin et al., 2001a; Volkov et al., 2003; Svensson et al., 2007). In applying these models to the deep-sea benthic environment, the evidence to date suggests that small-scale habitat variability and patchy disturbance, as well as global and regional variability, may play roles in maintaining deep-sea diversity (Snelgrove and Smith, 2002; Rex and Etter, 2010; Vanreusel et al., 2010; McClain et al., 2011). It is generally accepted that benthic distribution and diversity patterns can be related to abiotic factors such as geographical barriers, productivity gradients, sediment grain-size diversity, and current regimes, amongst others (e.g. Levin et al., 2001a, b; Rex and Etter, 2010). In turn, biotic factors may regulate deterministic biotic processes including colonisation, competition for food resources, predation, etc., leading to the largeand small-scale patterns in benthic fauna, but available data seem to suggest that particular attention should be paid to the scale relevant to the organism and their interactions when 
investigating such processes (Jumars, 1976). In marine biodiversity and ecosystem functioning studies, much attention is drawn to the processes themselves and the role played by single-species or limited-species groups (in an autecological approach), rather than applying a synecological approach whereby the community is investigated (Russell et al., 2011). Critical to gaining insights in synecological dynamics is identifying the scale at which the important processes occur. The current lack of understanding regarding the importance of scale impairs the advancement of our knowledge about biodiversity and ecosystem functioning as well as important underlying processes (Raffaelli and Friedlander, 2012), posing a limitation to further theoretical explorations (Paterson et al., 2012). An obvious step is to identify which spatial scale bears more importance in regulating community characteristics, an approach which has received relatively little attention in deep-sea scientific literature.

Despite the generally accepted view that processes on various spatial scales are driving different aspects of benthic communities, most of the evidence for the structure and dynamics of deep-sea communities and their causes originate from regional-scale sampling studies (Levin et al., 2001a), focusing on relatively large spatial scales $(10-100 \mathrm{~km})$, or typically on the scale of $0.1-10 \mathrm{~km}$. Unfortunately, the importance of micro-scale ( $\mathrm{cm}$ to $\mathrm{m}$ ) habitat variability and patchiness in this context has been demonstrated for only a small subset of species or taxa and for a limited number of habitats (Snelgrove and Smith, 2002). Whilst it is critical to choose the appropriate scale in investigating diversity patterns (Huston, 1999), studies seeking to document the important patterns and underlying processes for deep-sea benthic diversity and ecosystem functioning should consider the inherent scalability of patterns and processes and cover the whole spatial range. In addition, we are also confronted with the complexity of the benthic communities themselves. Benthic communities can be described in various ways (composition, structure, structural and functional diversity, standing stocks) and these descriptors may be affected differently by the various (a)biotic drivers that exist, and this variability may depend on the spatial scale investigated.

For the benthic meiofauna $(32-1000 \mu \mathrm{m}$, most abundant group of metazoans on Earth) in the deep sea, it has long been shown that smaller spatial scales $(\mathrm{cm})$ are particularly important to detecting diversity and distribution patterns (Thistle, 1978; Eckman and Thistle, 1988) and micro-scale variability of biogeochemical conditions and biotic interactions along the vertical sediment profile has been used to explain the structure of meiobenthic assemblages (Thiel, 1983; Jorissen et al., 1995; Soetaert et al., 2002; Braeckman et al., 2011; Ingels et al., 2011a, b). Knowledge on the importance of different spatial scales in shaping benthic patterns is essential in discerning the causative important processes. Without this knowledge, benthic faunal patterns may remain seemingly idiosyncratic without any understanding of the drivers of benthic diversity and functioning. In the absence of such understanding, conceptual models and their quantifications remain meaningless.

Among the deep-sea habitats, Submarine canyons can perhaps be considered as the most heterogenic topographic systems, with great levels of within- and inter-canyon variability across a range of ecologically relevant processes (Tyler et al., 2009; Vetter et al., 2010). Submarine canyons are typified by great habitat heterogeneity, the result of extreme topography, diverse current regimes and substratum types, and detrital funnelling, together exerting a powerful influence on biotic diversity (Levin et al., 2010). At the same time, each canyon is considered unique in its environmental settings, implying great variability between canyon systems and adding to the heterogeneity observed on across-canyon scales (Harris and Whiteway, 2011; Kiriakoulakis et al., 2011; Shepard and Dill, 1966). These canyon characteristics give support for their use in the present study to investigate the variable effects of scale in structuring deep-sea benthic assemblages.

The aim of this study was to investigate the importance of different spatial scales in determining benthic infauna communities (community structure, structural and functional diversity, standing stocks) through different drivers that act on different spatial scales. A combination of four different datasets from deep-sea submarine canyon/slope ecosystems at six different geographic areas in the Northeast (NE) Atlantic were analysed in terms of community structure, structural and functional diversity, and standing stocks on different spatial scales, using Nematoda as the most representative benthic component. The different spatial scales covered by the samples were Irish Margin and Western Iberian Margin (ca. $1500 \mathrm{~km}$ apart, interregional scale), distance between adjacent canyon/slope areas (50-200 km apart, regional scale), water depth (ca. 700, 1000, 3400 and $4300 \mathrm{~m}$, subregional scale), distance between different sampling locations or stations within a canyon $(5-50 \mathrm{~km}$ apart, macroscale), distance between cores from independent deployments (1-200 m apart, meso-scale), and vertical sediment depth differences $(1-5 \mathrm{~cm}$ per $\mathrm{cm}$, micro-scale) (Fig. 1). Given the supposition that the size scale of a group of organisms is important in identifying the structural and functional characteristics of their communities, we hypothesise that the sediment-dwelling meiofauna will be largely controlled by small-scale, local environmental conditions rather than large-scale differences between canyons, water depths and geographical areas or margins.

\section{Material and methods}

\subsection{Study areas}

The samples used in this study stem from various canyon and slope systems from two geographical areas of the northeast Atlantic, The Irish or Celtic Margin (IM) and the Western Iberian Margin (WIM). 


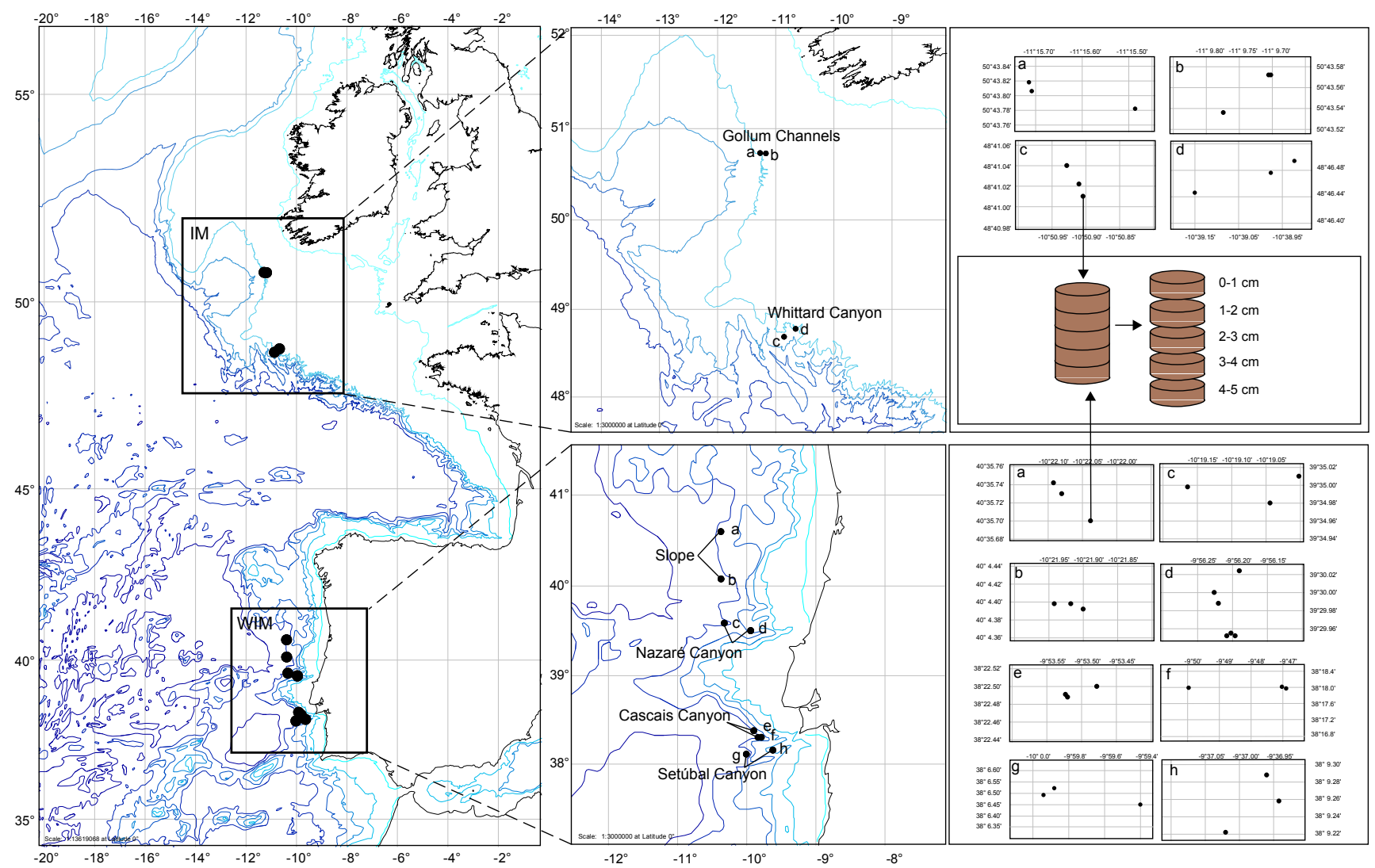

Fig. 1. Maps and diagram illustrating the different spatial scales of the sampling design. Left panel shows the geographic scale of the samples taken at two different margin systems in the northeast Atlantic; IM: Irish Margin, WIM: Western Iberian Margin. Middle panels show distribution of stations at each margin; letters correspond to panels on the right-hand side. Right upper panels show the distribution of the cores taken at IM; (a) Gollum Channels 1000 m; (b) Gollum Channels 700 m; (c) Whittard Canyon 1000 m; (d) Whittard Canyon 700 m. Right lower panels show the distribution of the cores taken at the WIM; (a) slope $3400 \mathrm{~m}$; (b) slope 4300 m; (c) Nazaré Canyon $4300 \mathrm{~m}$; (d) Nazaré Canyon 3400 m; (e) Cascais Canyon 4300 m; (f) Cascais Cayon 3400 m; (g) Setúbal Canyon 4300 m; (h) Setúbal Canyon 3400 m. Maps created with PanMap; M. Diepenbroek , H. Grobe and R. Sieger (2000) PanMap; http://www.pangaea.de/Software/PanMap.

The IM, situated in the NE Atlantic, is a highly productive system with significant primary production in the surface waters, which consequently supplies deep-sea sediments with high levels of organic matter and carbon (Lampitt et al., 1995; Longhurst et al., 1995) compared to other deep-sea areas. This is especially the case for mid-slope depths, which are influenced by additional export from the shelf or upper slope, where sediment organic loads are higher (Lampitt and Antia, 1997). At the Porcupine Seabight and further south along the Meriadzek Terrace, the margin is incised by numerous canyons and channels, which provide conduits for the transport of sediment from the shelf to the abyssal plain and over-bank turbidity currents, which deposit on the intervening terraces and spurs (Cunningham et al., 2005), but they also accumulate high amounts of sediments and organic matter. In addition, at the IM, cascading of dense water masses down the slope is likely to occur (Ivanov et al., 2004) and may entrain fresh chlorophyll material rapidly down slope, as reported by Hill et al. (1998). At the IM we studied the
Gollum Channel System and the Whittard Canyon. The Gollum Channel System is a tributary channel system incising the upper slope of the southeastern Porcupine Seabight, and converging into one main channel that opens into the Porcupine Abyssal Plain. Samples were taken in the most northerly channel, the Bilbo Channel, at ca. $700 \mathrm{~m}$ and $1000 \mathrm{~m}$ water depth (Ingels et al., 2011b). The upper $1000 \mathrm{~m}$ of the water column in this channel system is dominated by the eastern North Atlantic Water as well as the Mediterranean Outflow Water, resulting in relatively warm $\left(8-10^{\circ} \mathrm{C}\right)$ and saline water (ca. 35.5) between 700 and $1000 \mathrm{~m}$ water depth (White, 2006). The flow in the channel is dominated by the semidiurnal tide, with a significant downslope component and with currents strong enough to produce significant turbidity. The Whittard Canyon comprises several deeply incised branches, extending from the shelf break south of the Goban Spur. Sampling locations at ca. 700 and $1000 \mathrm{~m}$ water depth were situated on the interfluvial area between two upper NE branches (Ingels et al., 2006, 2011b). Downslope sediment 
transport is dominated by turbidity currents in the head of the canyon, causing mudflows to overspill the canyon walls and lead to deposition of mainly fine sediments in the adjacent areas.

The WIM comprises a narrow shelf and steep irregular slope, which is cut by various canyons. Hydrodynamic patterns in this area are mainly seasonal and are driven by seasonally varying winds which regulate the down- and upwelling regimes in winter and summer, respectively (Vitorino et al., 2002; Quaresma et al., 2007). The largest canyon, The Nazare Canyon, intersects the entire continental shelf and acts as a temporary sediment trap with intermittent transport of sediments and organic matter to the abyssal plain (de Stigter et al., 2007; Masson et al., 2011). Samples were taken at ca. 3400 and $4300 \mathrm{~m}$ water depth in the canyon (sedimentladen terrace, and canyon floor, respectively), and at similar depths along the adjacent slope to the north of the canyon (Ingels et al., 2009a). The relatively short Cascais Canyon begins at the shelf edge southwest of the mouth of the Tagus Estuary and extends to the Tagus Abyssal Plain. The Setúbal Canyon cuts the continental shelf close to the Sado River Estuary, and also leads to the Tagus Abyssal Plain. Comparable sedimentation regimes have been observed for both the Cascais and Setúbal canyons, with accumulation of sediment in the upper parts and limited down-canyon transport (de Stigter et al., 2011). Current regimes seem variable in both canyons. Samples in both canyons were taken at ca. 3400 and $4300 \mathrm{~m}$ water depth, and more or less along the axes of the canyons (Ingels et al., 2011a).

\subsection{Sampling strategy and processing}

Six datasets (see data references: Ingels et al., 2009b, 2011d, $\mathrm{e}, \mathrm{f}, \mathrm{g}, \mathrm{h}$ ) from four different deep-sea canyon studies (Ingels et al., 2009a, 2011a, b, c) were merged (totalling 17273 nematode individuals belonging to 248 different genera) to investigate the important spatial scales of variability in structure, diversity and function of small sediment-dwelling fauna in the deep sea. All the data is publicly available through the Pangaea data depository (www.pangaea.de); DOI codes for data are given in Table 1 and the citations for these datasets are mentioned in the References section. The samples cover two geographically distinct margins (IM, WIM) which lie about $1500 \mathrm{~km}$ apart. For each margin, several canyon/slope areas were sampled by means of a coring device (for details on coring devices see Table 1), all producing sediment cores with an intact sediment-water interface and similar crosssurface areas (maximum difference between sample surfaces was ca. $2.7 \mathrm{~cm}^{2}$, Table 1). This allowed comparison between samples irrespective of the sampling technique used. At each of the six canyon/slope areas, cores were taken at two different stations (ca. 700 and $1000 \mathrm{~m}$ for the IM, and ca. 3400 and $4300 \mathrm{~m}$ for the WIM). At each location, a minimum of three independent (repeated deployments of the coring device) cores were taken which lay 1 to $200 \mathrm{~m}$ apart. Each sed- iment core was subsequently split into $1 \mathrm{~cm}$ layers down to $5 \mathrm{~cm}$ vertical depth, whereby each $1 \mathrm{~cm}$ slice was treated independently. On some occasions, only the surface $1 \mathrm{~cm}$ of sediment was available for analysis. An overview of the sampling design and meta-information on the samples is given in Fig. 1 and Table 1. A total of 162 samples were used for this study.

Nematoda, the most abundant metazoan phylum in the marine environment, was used as a model taxon for the small benthic fauna. Borax-buffered formalin (4\%) sediment samples were used to extract the meiofauna using standard procedures (Heip et al., 1985; 32-1000 $\mu \mathrm{m}$ sieves, LUDOX HS as centrifugation medium) to separate the organisms from the sediment particles. All nematodes were counted and between 100 and 150 individuals were picked out randomly from each $1 \mathrm{~cm}$ sample, transferred to glycerine (Seinhorst, 1959) and mounted on slides. All nematodes were identified under a compound microscope $(100 \times$ magnification) to genus level using Platt and Warwick (1988), taxonomic literature of the Nematode Library at Ghent University, and the NeMys nematode database and identification keys (Deprez et al., 2005; nemys.ugent.be). Specimens that could not be identified to the genus level were assigned to the appropriate higher taxon level. All individuals were grouped into four feeding types based on buccal morphology and teeth composition sensu Wieser (1953): selective deposit feeders (1A), non-selective deposit feeders (1B), epistratum feeders (2A), and predators/scavengers or omnivores (2B). This classification was amended with one extra group to account for "chemosynthetic" nematodes that lack a mouth and buccal cavity, have a degenerated alimentary canal and live in association with symbiotic micro-organisms (Ingels et al., 2011b). In addition, each nematode individual was assigned a $\mathrm{c}-\mathrm{p}$ score (score from 1 to 5 reflecting life history with 1 represents colonizer and 5 represents persister; in this context colonizers are regarded as r-strategists, and persisters are regarded to be k-strategists; cf. Bongers (1990) and Bongers et al. (1991)). Length (excluding filiform tails) and maximum width were measured using a Leica DMR compound microscope and Leica LAS 3.3 imaging software; these measurements were used to calculate biomass according to the formula in Table 2 .

\subsection{Sampling design and data treatment}

Various descriptors for nematode community structure, structural and functional diversity, and standing stock were used to test the importance of different scales in determining community patterns (Table 2). Community structure was determined by using the relative abundances of genera in the sample assemblage. Structural diversity descriptors used were the four Hill numbers (Hill, 1973) and expected number of genera for a normalised sample size of 51 individuals $(\mathrm{EG}(51))$, based on the formula by Sanders (1968) which was later corrected by Hurlbert (1971). Hill numbers were used because they give a measure of both richness, 
Table 1. Information on the samples used for this study. WD: water depth; Surface: surface area of the sample; SD: sediment depth. * indicates a subcore was taken from a $100 \mathrm{~mm}$-diameter core.

\begin{tabular}{|c|c|c|c|c|c|c|c|c|c|c|c|c|c|c|}
\hline DOI & Cruise & Margin & Area & Station & Cast/Dive & core & Lat & Long & $\mathrm{WD}(\mathrm{m})$ & WD class & Surface & Gear & Sampling Date & $\mathrm{SD}(\mathrm{cm})$ \\
\hline A & D297 & WIM & Nazaré & D15735 & 1 & $\mathrm{a}$ & 39.58330 & -10.31940 & 4340 & 4300 & 25.518 & MegaCorer & $2 / 08 / 2005$ & $0-1$ \\
\hline A & D297 & WIM & Nazaré & D15737 & 1 & a & 39.50000 & -9.93710 & 3453 & 3400 & 25.518 & MegaCorer & $2 / 08 / 2005$ & $0-1$ \\
\hline A & D297 & WIM & Nazaré & D15753 & 1 & $\mathrm{a}$ & 39.50040 & -9.93650 & 3528 & 3400 & 25.518 & MUC & $8 / 08 / 2005$ & $0-5$ \\
\hline A & D297 & WIM & Nazaré & D15753 & 2 & a & 39.49980 & -9.93700 & 3425 & 3400 & 25.518 & MUC & $8 / 08 / 2005$ & $0-1$ \\
\hline A & D297 & WIM & Nazaré & D15758 & 3 & $\mathrm{a}$ & 39.58300 & -10.31740 & 4435 & 4300 & 25.518 & MUC & $9 / 08 / 2005$ & $0-5$ \\
\hline A & D297 & WIM & Nazaré & D15758 & 4 & $\mathrm{a}$ & 39.58350 & -10.31670 & 4335 & 4300 & 25.518 & MUC & $9 / 08 / 2005$ & $0-1$ \\
\hline A & D297 & WIM & Slope & D15770 & 1 & $\mathrm{a}$ & 40.07327 & -10.36530 & 4277 & 4300 & 25.518 & MUC & $14 / 08 / 2005$ & $0-5$ \\
\hline A & D297 & WIM & Slope & D15770 & 2 & $\mathrm{a}$ & 40.07317 & -10.36500 & 4275 & 4300 & 25.518 & MUC & $14 / 08 / 2005$ & $0-1$ \\
\hline A & D297 & WIM & Slope & D15770 & 3 & $\mathrm{a}$ & 40.07333 & -10.36570 & 4275 & 4300 & 25.518 & MUC & $15 / 08 / 2005$ & $0-1$ \\
\hline A & D297 & WIM & Slope & D15771 & 1 & $\mathrm{a}$ & 40.59500 & -10.36730 & 3400 & 3400 & 25.518 & MUC & $15 / 08 / 2005$ & $0-5$ \\
\hline A & D297 & WIM & Slope & D15771 & 1 & $\mathrm{~b}$ & 40.59550 & -10.36800 & 3401 & 3400 & 25.518 & MUC & $15 / 08 / 2005$ & $0-1$ \\
\hline A & D297 & WIM & Slope & D15771 & 3 & $\mathrm{a}$ & 40.59567 & -10.36820 & 3403 & 3400 & 25.518 & MUC & $15 / 08 / 2005$ & $0-1$ \\
\hline B & CD179 & WIM & Cascais & CD56838 & 3 & 11 & 38.10820 & -9.99900 & 4482 & 4300 & 28.274 & MegaCorer* & $4 / 05 / 2006$ & $0-5$ \\
\hline B & CD179 & WIM & Cascais & CD56838 & 4 & 8 & 38.10870 & -9.99980 & 4485 & 4300 & 28.274 & MegaCorer* & $4 / 05 / 2006$ & $0-5$ \\
\hline B & CD179 & WIM & Cascais & CD56842 & 1 & 7 & 38.10750 & -9.99900 & 4482 & 4300 & 28.274 & MegaCorer & $5 / 05 / 2006$ & $0-5$ \\
\hline B & CD179 & WIM & Cascais & CD56836 & 1 & 1 & 38.29980 & -9.83270 & 3209 & 3400 & 28.274 & MegaCorer* & $1 / 05 / 2006$ & $0-5$ \\
\hline B & CD179 & WIM & Cascais & CD56823 & 2 & 11 & 38.30020 & -9.78370 & 3218 & 3400 & 28.274 & MegaCorer* & $27 / 04 / 2006$ & $0-5$ \\
\hline B & CD179 & WIM & Cascais & CD56821 & 2 & 2 & 38.29950 & -9.78150 & 3214 & 3400 & 28.274 & MegaCorer* & $27 / 04 / 2006$ & $0-5$ \\
\hline B & CD179 & WIM & Setùbal & CD56837 & 7 & 2 & 38.37480 & -9.89200 & 4243 & 4300 & 28.274 & MegaCorer* & $3 / 05 / 2006$ & $0-5$ \\
\hline B & CD179 & WIM & Setùbal & CD56837 & 8 & 5 & 38.37480 & -9.89200 & 4244 & 4300 & 28.274 & MegaCorer & $3 / 05 / 2006$ & $0-5$ \\
\hline B & CD179 & WIM & Setùbal & CD56837 & 5 & 8 & 38.37500 & -9.89130 & 4241 & 4300 & 28.274 & MegaCorer* & $2 / 05 / 2006$ & $0-5$ \\
\hline B & CD179 & WIM & Setùbal & CD56810 & 1 & 2 & 38.15370 & -9.61700 & 3224 & 3400 & 28.274 & MegaCorer* & $23 / 04 / 2006$ & $0-5$ \\
\hline B & CD179 & WIM & Setùbal & CD56804 & 6 & 8 & 38.15430 & -9.61570 & 3275 & 3400 & 28.274 & MegaCorer* & $21 / 04 / 2006$ & $0-5$ \\
\hline B & CD179 & WIM & Setùbal & CD56806 & 1 & 6 & 38.15480 & -9.61600 & 3275 & 3400 & 28.274 & MegaCorer* & $21 / 04 / 2006$ & $0-5$ \\
\hline $\mathrm{C}$ & JC10 & WIM & Nazaré & 95-PUC02 & 48 & 2 & 39.49923 & -9.93675 & 3512 & 3400 & 25.518 & PC (ISIS) & $12 / 06 / 2007$ & $0-5$ \\
\hline D & JC10 & WIM & Nazaré & 95-PUC03 & 48 & 3 & 54.86667 & -9.93663 & 3512 & 3400 & 25.518 & PC (ISIS) & $12 / 06 / 2007$ & $0-5$ \\
\hline E & JC10 & WIM & Nazaré & 95-PUC09 & 48 & 9 & 54.91667 & -9.93665 & 3512 & 3400 & 25.518 & PC (ISIS) & $12 / 06 / 2007$ & $0-5$ \\
\hline $\mathrm{F}$ & Belgica 2006/13 & IM & Gollum & GOL700 & 1 & 4 & 50.72563 & -11.16289 & 740 & 700 & 25.518 & MidiCorer* & $24 / 06 / 2006$ & $0-5$ \\
\hline $\mathrm{F}$ & Belgica 2006/13 & IM & Gollum & GOL700 & 10 & 4 & 50.72622 & -11.16174 & 770 & 700 & 25.518 & MidiCorer* & $25 / 06 / 2006$ & $0-5$ \\
\hline $\mathrm{F}$ & Belgica 2006/13 & IM & Gollum & GOL700 & 10bis & 2 & 50.72622 & -11.16174 & 770 & 700 & 25.518 & MidiCorer* & $25 / 06 / 2006$ & $0-5$ \\
\hline $\mathrm{F}$ & Belgica 2006/13 & IM & Gollum & GOL1000 & 2 & 3 & 50.72970 & -11.25814 & 1085 & 1000 & 25.518 & MidiCorer* & $24 / 06 / 2006$ & $0-5$ \\
\hline $\mathrm{F}$ & Belgica 2006/13 & IM & Gollum & GOL1000 & 4 & 3 & 50.73013 & -11.26183 & 1094 & 1000 & 25.518 & MidiCorer* & $25 / 06 / 2006$ & $0-5$ \\
\hline $\mathrm{F}$ & Belgica 2006/13 & IM & Gollum & GOL1000 & 5 & 3 & 50.73028 & -11.26186 & 1075 & 1000 & 25.518 & MidiCorer* & $25 / 06 / 2006$ & $0-5$ \\
\hline $\mathrm{F}$ & Belgica 2006/13 & IM & Whittard & WHS700 & 2 & 1 & 48.77410 & -10.65248 & 708 & 700 & 25.518 & MidiCorer* & $26 / 06 / 2006$ & $0-5$ \\
\hline $\mathrm{F}$ & Belgica 2006/13 & IM & Whittard & WHS700 & 3 & 1 & 48.77488 & -10.64867 & 815 & 700 & 25.518 & MidiCorer* & $26 / 06 / 2006$ & $0-5$ \\
\hline $\mathrm{F}$ & Belgica 2006/13 & IM & Whittard & WHS700 & 4 & 1 & 48.77460 & -10.64961 & 764 & 700 & 25.518 & MidiCorer* & $26 / 06 / 2006$ & $0-5$ \\
\hline $\mathrm{F}$ & Belgica 2006/13 & IM & Whittard & WHS1000 & 1 & 4 & 48.68402 & -10.84876 & 1155 & 1000 & 25.518 & MidiCorer* & $26 / 06 / 2006$ & $0-5$ \\
\hline $\mathrm{F}$ & Belgica 2006/13 & IM & Whittard & WHS 1000 & 2 & 4 & 48.68370 & -10.84855 & 1155 & 1000 & 25.518 & MidiCorer* & $26 / 06 / 2006$ & $0-5$ \\
\hline $\mathrm{F}$ & Belgica 2006/13 & IM & Whittard & WHS 1000 & 3 & 4 & 48.68347 & -10.84836 & 1175 & 1000 & 25.518 & MidiCorer* & $26 / 06 / 2006$ & $0-5$ \\
\hline
\end{tabular}

Digital Object Identifiers (DOIs) for nematode datasets: A: 10.1594/PANGAEA.776602, B: 10.1594/PANGAEA.776656, C: 10.1594/PANGAEA.777030, D: 10.1594/PANGAEA.777032, E: 10.1594/PANGAEA.777033, F: 10.1594/PANGAEA.776716. Citations to datasets are included in the References section. "0-1" indicates only the surface $1 \mathrm{~cm}$ was available for analysis; " $0-5$ " indicates that the sediment slices $0-1,1-2,2-3,3-4,4-5 \mathrm{~cm}$ were individually available for analysis. Megacorer: Corer fitted with $60 \mathrm{~mm}$ (internal diameter) plexiglass cores (Ocean Scientific International Ltd), MUC: Barnett-type multicorer fitted with $57 \mathrm{~mm}$ (internal diameter) plexiglass cores, PC (ISIS): $57 \mathrm{~mm}$ (internal dianeter) push core operated by the Remote Operated Vehicle ISIS (NOCS).

as well as equitability (evenness) of the communities studied (Heip et al., 1998). As functional diversity descriptors, we used trophic diversity (TD) and the maturity index (MI). We used the reciprocal value of TD as defined by Heip et al. (1998), so that higher values correspond with higher trophic complexity, and it was modified for use with the four Wieser (1953) feeding groups and the extra "chemosynthetic" guild (Ingels et al., 2011b). The MI was originally defined by Bongers (1990) for soil nematodes, but has been applied to marine nematode communities (Bongers et al., 1991). The MI is a useful descriptor in that it characterises the community in terms of life history and life strategies of its members and has been successfully used to infer various types of disturbance and subsequent recolonisation processes. Similarly to TD, MI is based on autecological information, but it is based on a broader character complex.

We distinguished the four different descriptor groups by means of a 2nd stage MDS and a SIMPROF test on the different community descriptors. This procedure allowed us to identify whether different descriptors are able to characterize different aspects of the communities by looking for statistically significant clusters in the descriptors (Clarke and Gorley, 2006; Clarke et al., 2006). The results of these analyses are shown in Fig. A1 (Supplement, Appendix A, Fig. A1) and support the grouping of the descriptors in the four sets used in this study. To assess the significance of different scale effects in determining deep-sea meiofauna communities, the four different sets of community descriptors were analysed (Table 2). The descriptor sets were analysed by means of multivariate Permutational Analyses of Variance (PERMANOVA; Anderson, 2005) using PERMANOVA+ and Primer v6 (Clarke and Gorley, 2006; Anderson et al., 2008). Genera relative abundance data were standardised for sample size, square-root transformed, and Bray-Curtis was used as a similarity measure. The diversity descriptor data (Hill numbers, EG(51)) were normalised sensu Clarke and Gorley (2006) and Euclidean distance was used to construct the resemblance matrix. The same diversity data treatment 
Table 2. Descriptors used to characterise the community, including the formulas used, explanations of the formula components, and references.

\begin{tabular}{|c|c|c|c|c|}
\hline Community characteristic & Descriptor & Formula & Formula components & References \\
\hline Assemblage structure & Genera relative abundances & - & - & - \\
\hline \multirow[t]{2}{*}{ Diversity } & $\begin{array}{l}H_{0} \text { (genus richness) } \\
H_{1} \text { (genus richness and evenness) } \\
H_{2} \text { (genus richness and evenness) } \\
H_{\text {inf }} \text { (genus evenness) }\end{array}$ & $H_{a}=\left(\sum_{i} p_{i}^{a}\right)^{1 /(1-a)}$ & $\begin{array}{l}\text { - } p_{i}=\text { relative proportion of genus } i \text { in sam- } \\
\text { ple } \\
\text { - } a \text { defines the order of the Hill number }\end{array}$ & (Hill, 1973; Heip et al., 1998) \\
\hline & EG(51) (genus richness) & $\sum_{i=1}^{g}\left(1-\frac{\left[\begin{array}{c}N-N_{i} \\
n\end{array}\right]}{\left[\begin{array}{l}N \\
n\end{array}\right]}\right)$ & $\begin{array}{l}\text { - } N_{i}=\text { the number of individuals belonging } \\
\text { to genus } i \text { in the full sample } \\
\text { - } n=\text { number of individuals in normalized } \\
\text { sample size } \\
\text { - } g=\text { number of genera } \\
\text { - square bracket notation }\left[\begin{array}{l}A \\
B\end{array}\right] \text { indicates } \\
\text { number of permutations of } A \text { elements in } \\
\text { groups of size } B\end{array}$ & $\begin{array}{l}\text { (Hurlbert, 1971; Heip et al., 1998) } \\
\text { Adapted for normalized sample size of } 51 \text { indi- } \\
\text { viduals }\end{array}$ \\
\hline \multirow[t]{2}{*}{ Function } & TD (trophic diversity) & $\left(\sum_{i=1}^{n} q_{i}^{2}\right)^{-1}$ & $\begin{array}{l}\text { - } q_{i}=\text { proportion of feeding type } i \text { in the as- } \\
\text { semblage } \\
\text { - } n=\text { number of feeding types (5) }\end{array}$ & $\begin{array}{l}\begin{array}{l}\text { Reciprocal of index defined by Heip } \\
\text { et al. (1998) }\end{array} \\
\end{array}$ \\
\hline & MI (maturity index) & $\sum_{i=1}^{n} v_{i} * p_{i}$ & $\begin{array}{l}\text { - } p_{i}=\text { relative proportion of genus } i \text { in } \\
\text { sample } \\
\text { - } v_{\mathrm{i}}=\mathrm{c}-\mathrm{p} \text { score }\end{array}$ & (Bongers, 1990; Bongers et al., 1991) \\
\hline \multirow[t]{2}{*}{ Standing stock } & Total nematode abundance (ind. $/ 10 \mathrm{~cm}^{2}$ ) & - & - & - \\
\hline & Biomass $\left(\mu \mathrm{g}\right.$ dry weight $/ 10 \mathrm{~cm}^{2}$ ) & $\sum_{i}\left[\frac{\sum_{x_{i}}\left[\frac{L \cdot W^{2}}{1.6 \times 10^{6}}\right]_{x}}{x_{i}} * p_{i}\right] \cdot A$ & $\begin{array}{l}\text { - } p_{i}=\text { relative proportion of genus } i \text { in } \\
\text { sample } \\
\text { - } L=\text { length, } W=\text { maximum width } \\
\text { - } x_{i}=\text { number of individuals belonging to } \\
\text { genus } i \\
\text { - } A=\text { total nematode abundance } \\
\text { (ind. } / 10 \mathrm{~cm}^{2} \text { ) }\end{array}$ & $\begin{array}{l}\text { Based on Andrassy (1956) } \\
\text { As used in Ingels et al. (2011b) }\end{array}$ \\
\hline
\end{tabular}

was applied to the sets of standing stock (total abundance, total biomass) and functional diversity descriptors (TD, MI).

For the PERMANOVA tests, we used two mixed-model hierarchical designs with three and four factors. For the three-way model, we used the factors: margin (WIM and IM; fixed; about $1500 \mathrm{~km}$ apart, interregional scale), area (Ar; random and nested in margin; with levels "Whittard', "Gollum", "Nazaré", "Setúbal", "Cascais", "Slope"; 50-200 km apart; regional scale) and water depth (WD; random and nested in Margin; with levels "700 m", " 1000 m", " 3400 m", " $4300 \mathrm{~m}$ "; subregional scale). The levels for the factors area and water depth are not replicated for each margin and these factors are therefore nested in the factor margin. The 4-way PERMANOVA model is applied to each margin separately and has the following factors: area (Ar, fixed, with levels "Whittard" and "Gollum" for the IM test, and "Nazaré", "Setúbal", "Cascais", and "Slope" for the WIM test; regional scale), water depth (WD, fixed, with levels " $700 \mathrm{~m}$ " and " $1000 \mathrm{~m}$ " for the IM test, and " $3400 \mathrm{~m}$ " and " $4300 \mathrm{~m}$ " for the WIM test; subregional scale), core (Co, random, identifying each core in the dataset to account for variability within the station level; 1-200 m apart on a horizontal scale; mesoscale), and sediment depth (SD, fixed, with levels " $0-1$ ", "1-2", "2-3", "3-4", "4-5", identifying each $1 \mathrm{~cm}$ sediment layer; micro-scale). The interaction between Area and Water Depth accounts for the differences between sampling locations or stations and is defined as the macro-scale.
The non-replicated nature of the vertical sediment layers within each core warranted a split plot design for the 4way model with Co nested in Ar and WD, leading to a repeated measures analysis, whereby the main-factor test was followed by a pairwise comparison test within each significant double or triple factor interaction term to investigate significant effects in the full-model test. The nesting of $\mathrm{Co}$ in $\mathrm{Ar}$ and WD had as a consequence that the variability contained in the term $\mathrm{Co}(\mathrm{Ar} \times \mathrm{WD}) \times \mathrm{SD}$, indicative of the variability of each layer within each core, is included in the residual term, leading to a more conservative test. Because of the unbalanced design (not all sediment layers are fully replicated for each $\mathrm{Ar} \times$ WD combination) in the PERMANOVA model we used type III sums of squares (partial) leading to a conservative test while maintaining independence between terms. To assess the magnitude of the spatial variation at each spatial scale we used the estimated components of variation (ECV) as a percentage of the total variation. When negative variance components were encountered, these were set to zero in the assumption that they were sample underestimates of small or zero variances (Benedetti-Cecchi, 2001; Fletcher and Underwood, 2002). Several non-metrical multidimensional scaling plots (MDS) were used to illustrate the variability contained within each descriptor set and visualise the main-factor and interaction effects. Non-metric MDS plots are preferred over other, constrained plots, because the MDS procedure captures the total variability inherent to the data. Constrained 
ordinations highlight the importance of certain factors and can give a distorted view of what is contained within the data.

\section{Results}

\subsection{3-way PERMANOVA test: interregional, regional and macro-scale}

The 3-way PERMANOVA test indicated limited differences between the IM and the WIM (Table 3). Significant differences on this interregional scale were only found for community structure and structural diversity $(p=0.003$ and $p=0.048$, respectively). In this test, community structure differences between stations in each area $(19.6 \%$, Ar $(\mathrm{M}) \times \mathrm{WD}(\mathrm{M}))$ are greater than margin differences $(16 \%)$, whilst for structural diversity only differences between margins are significant ( $15.5 \%$ of variability explained, Table 3 ). For functional diversity, significant differences were found between areas, explaining $7.7 \%$ of total variability. Only about $16 \%$ of total variability is explained by margin differences for community structure and structural diversity, whilst most of the variability is contained within the residual term as shown by the ECV values in Table 3. The limitations of the 3 -way test design imply that variability caused by differences on smaller spatial scales (meso- and macro-scale, or core and sediment depth differences, respectively) is included in the residual term. The relatively low contributions to variability for most factors is mirrored in the high contributions of the residual term (ECV \% between 57.4 and $88.5 \%$ for the different descriptors, Table 3) and hence attributable to the differences occurring at the smaller spatial scales. Nevertheless, the nMDS plots B, C and D in Fig. 2 illustrate the differences in Bray-Curtis space between the margins in terms of community structure, with only a small overlap between the planes covered by the samples of each margin. However, the large residual variability and absence of the smaller spatial scales in the 3-way test warrants an analysis that includes these scales in the test model, and this is done in the 4-way PERMANOVA for each margin separately.

\subsection{4-way PERMANOVA test: regional, macro-, meso- and macro-scale}

In general, regional-scale differences (between different areas within each margin) were a significant and important cause of community structure variability as indicated by the 4-way PERMANOVA results (Table 3, Fig. 3a). The relative effect sizes on the regional scale were larger for the WIM $(12.5 \%)$ than for the IM $(8.2 \%)$, which is also illustrated by the differential size of overlap between the grey-shaded margin areas in Fig. 2c, and corroborates the idea that nematode community differences between canyons at the WIM are more pronounced compared to the IM. Figure $2 \mathrm{c}$ illustrates the different levels of community variability contained within each area as attested by the ECV values in Fig. 3a and
Table 3. For structural diversity, regional-scale differences were also significant, with much greater variability observed at the WIM (7.6\%) compared to the IM (1.7\%) (Table 3, Fig. 3b). For functional diversity, regional-scale differences were significant but explain only a minor part of total variability, with ECV values of $7.1 \%$ and $8.3 \%$ for the WIM and IM, respectively (Table 3, Fig. 3d). In terms of standing stocks, no significant differences were observed between areas at each margin.

Subregional-scale variability (between water depths) in community structure was the least important of all main factors tested at both margins, and the significant differences between 3400 and $4300 \mathrm{~m}$ water depth (WIM, 3.5\%) were smaller than between 700 and $1000 \mathrm{~m}$ water depth (IM, $6.3 \%$ ) (Table 3, Fig. 3). This can also be seen by the differential overlap of the water depth groups on the nMDS plot of Fig. 2d. In terms of structural diversity, the water depth effect contributed $6.9 \%$ and $4.5 \%$ of total variability for the WIM and IM, respectively (Table 3). Subregional differences in functional diversity were only significant at the IM where they contribute $9.1 \%$ to the total observed variability (Table 3, Fig. 3d). In terms of standing stocks, no significant differences were observed between areas at each margin.

It is on the macro-scale (between stations) that the largest significant nematode community differences were observed for both margins (Fig. 3c, Table 3), highlighting the pronounced differences between communities from different stations. The test results show that these differences were smaller at the WIM (18.4\%) than at the IM (20.5\%). Looking at structural diversity, significant station differences were only exhibited at the IM, but the differences were small and explained only $2.6 \%$ of total variability. The stations at the WIM, on the other hand, did not show any differences in terms of structural diversity. In contrast, functional diversity differences between stations were only significant for the WIM, but the contribution to total variability was relatively low $(6.7 \%)$. No significant differences between stations were found for standing stocks.

Meso-scale community structure differences (between cores at each station) were significant $(p<0.01)$ but relatively low compared to the other spatial scales, accounting for only $5.9 \%$ and $6.4 \%$ of total variability at the WIM and IM, respectively $(\mathrm{Co}(\mathrm{WD} \times \mathrm{Ar})$, Table 3 , Fig. 3a). The variability attributed to the community structure differences between cores at each station is most likely an indication of patchiness or heterogeneity at each station. For structural and functional diversity, and standing stocks there were no significant differences between independent cores at each station, suggesting these descriptors do not change on this scale and hence within-station heterogeneity is not expressed in structural and functional diversity, and standing stocks.

On the micro-scale (between sediment depth layers), we observed significant community structure differences of similar magnitude to community differences at the regional scale, with $10.0 \%$ and $11.9 \%$ of total variability attributed 


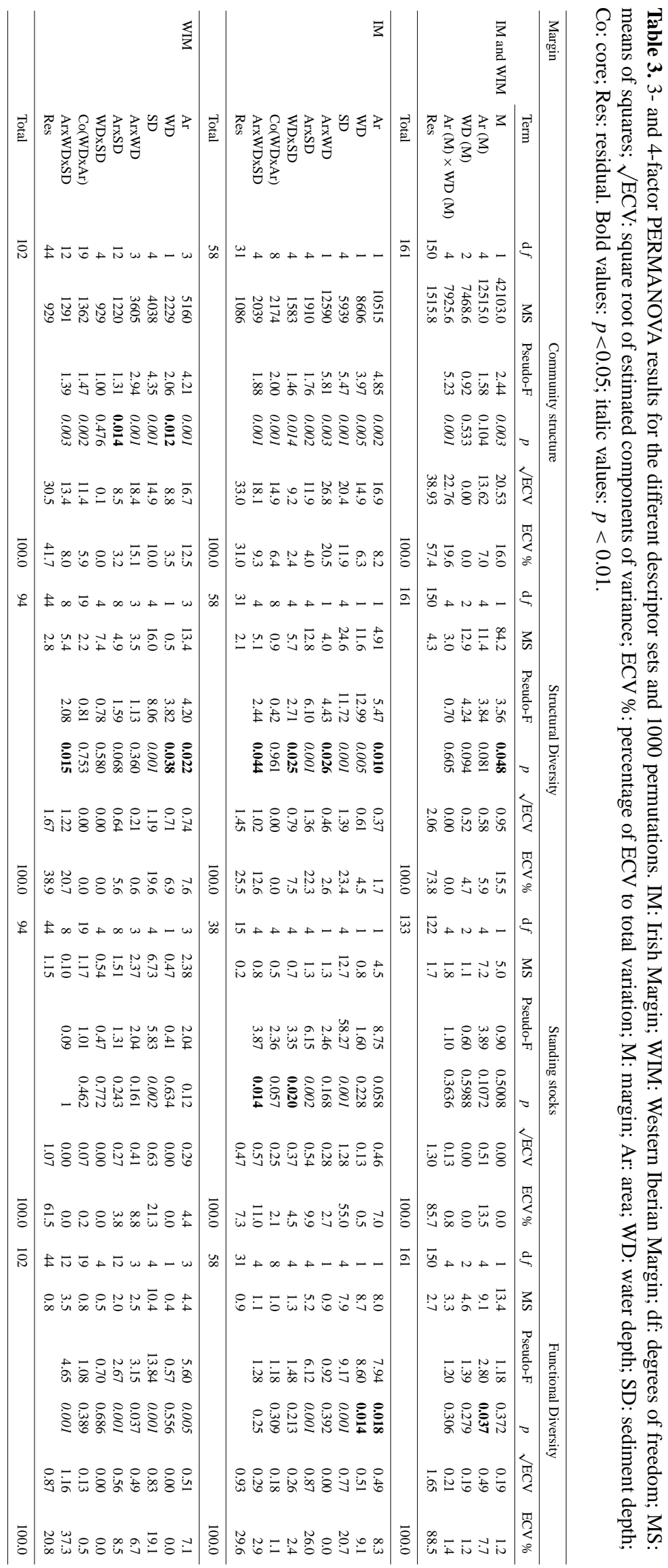



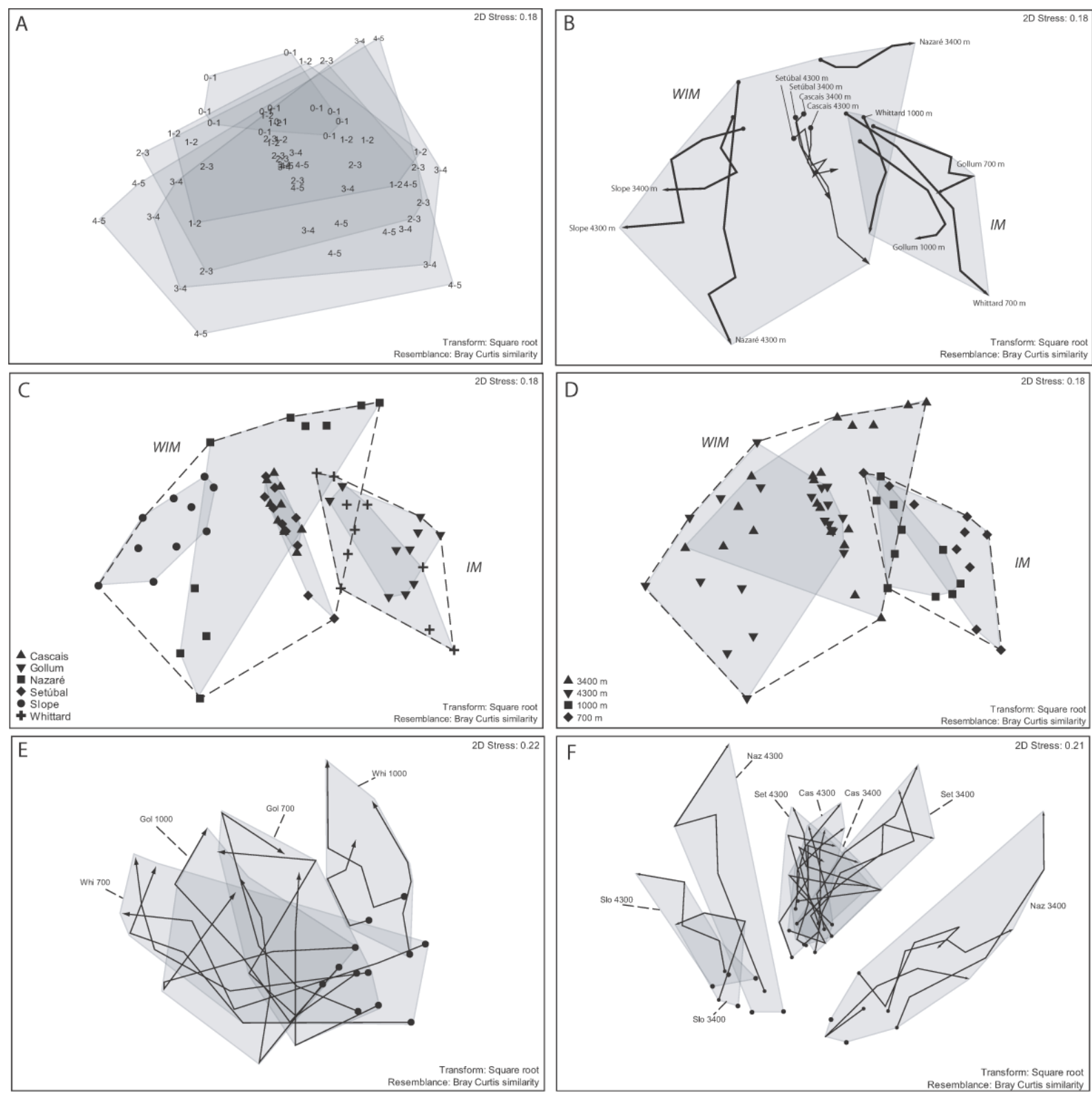

Fig. 2. Non-metric multidimensional scaling plots of Bray-Curtis similarity matrices based on standardised, square root-transformed genera abundance data. (A-D) based on averaged data per station (averaged over cores per station for each station (Ar $\times$ WD combination). (A) labels denote sediment depth in $\mathrm{cm}$; grey planes encompass variability for each sediment layer by connecting the outer data points. (B) same plot as (A), but lines connect consecutive sediment layers within each core $(\bullet=0-1 \mathrm{~cm}, \boldsymbol{\nabla}=4-5 \mathrm{~cm}$ with the other sediment layer points in between connected along the vertical sediment profile); grey planes represent different margins; IM: Irish Margin; WIM: Western Iberian Margin. (C) same as (A), but symbols and grey planes denote the different areas; outer points belonging to the same margin are connected with dashed lines. (D) same as (C), but symbols and grey planes denote different water depths. (E-F) based on unaveraged data whereby each core is represented seperately. (E) Irish Margin; lines connect consecutive sediment layers within each core $(\bullet=0-1 \mathrm{~cm}, \bullet=4-5 \mathrm{~cm}$ with the other sediment layer points in between connected along the vertical sediment profile); grey planes represent stations. $(\mathbf{F})$ Western Iberian Margin; lines connect consecutive sediment layers within each core $(\bullet=0-1 \mathrm{~cm}, \bullet=4-5 \mathrm{~cm})$; grey planes represent stations.

to sediment depth differences at the WIM and IM, respectively. The micro-scale effect on community structure is clearly illustrated in Bray-Curtis space in Fig. 2a, showing the increasing variability contained within deeper sediment depth layers. The $0-1 \mathrm{~cm}$ layers group tightly (smallest grey area), while with increasing sediment depth the resemblance between samples gradually increases, with maximum variability exhibited for the $4-5 \mathrm{~cm}$ layer. For structural diversity, clearly the main factor causing variability was sediment depth $(19.6 \%$ and $23.4 \%$ of total variability explained at the 

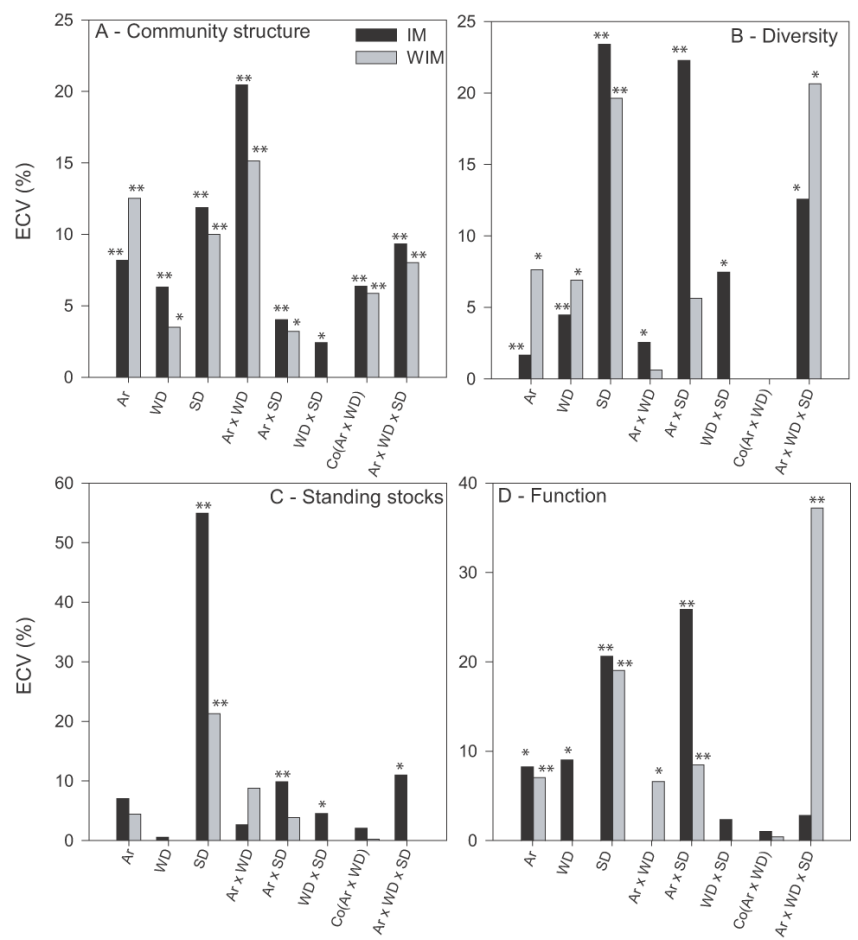

Fig. 3. Percentages of estimated components of variation from the PERMANOVA tests for different descriptor sets. IM: Irish Margin; WIM: Western Iberian Margin; Ar: area; WD: water depth; SD: sediment depth; Co: core. * indicates significance of the PERMANOVA tests at $p<0.05$; ** indicates significance at $p<0.01$.

WIM and IM, respectively, Table 3). Looking at the functional diversity, it was also the micro-scale that comprised most variability at both margins with sediment depth effect sizes around $20 \%$. For standing stocks, the only significant differences were found on the micro-scale, with sediment depth differences being more important at the IM than at the WIM (Table 3, Fig. 3c).

For community structure, several double interaction terms and the three-way interaction were significant (Table 3, Fig. 3a), warranting further investigation by means of pairwise comparisons (Supplement, Appendix B, Table B1). These results indicated that community structure differences on the micro-scale are variable between different areas and water depths for both margins. At the IM, for instance, community structure differences between the different sediment layers are similar for all stations, whilst for the WIM, sediment depth variation changes considerably for different stations. These community structure sediment depth patterns can be observed in Fig. 2B; the lines that connect the different sediment layers for each station vary in length and direction depending on the station. Similar observations are made at the macro-scale, with community structure differences between stations being more pronounced for the Nazaré Canyon area compared to the Cascais and Setúbal canyon areas. In general, significant interactions between two fac- tors indicate that differences between levels of one factor are differently expressed in the different levels of the other factor and this can be observed in Table A1 for community structure and is exhibited by the patterns in the relevant community structure nMDS plot in Fig. 2.

As for community structure, the significant interaction terms resulting from the structural diversity test indicate that micro-scale differences are variable depending on which area, water depth or station is considered. The reason behind the large Area $\times$ Sediment $\times$ Depth interaction at the IM lies in the fact that the sediment depth differences in structural diversity are highly variable in the Gollum and Whittard areas (Figs. 3b, 4a) and this is confirmed by the pairwise comparison tests (Supplement, Appendix B, Table B2). The same is true when considering the different water depth levels at the IM. In contrast, structural diversity sediment depth differences are similar for the different areas and water depths at the WIM (Table 3, Figs. 3b, 4b). The significant three-way interaction $(\mathrm{Ar} \times \mathrm{WD} \times \mathrm{SD})$ for both margin tests show that sediment depth differences in structural diversity are differently expressed at the different stations.

The same can be said for the functional diversity results; significant interactions between factors and subsequent pairwise comparisons (Supplement, Appendix A, Table A3) indicate that the sediment depth differences for functional diversity are variable between different areas at each margin, but this variability is more pronounced at the IM than at the WIM. Hence, functional diversity appears to change more along the vertical profile when the Gollum Channel and Whittard Canyon are compared than when the WIM Margin areas are compared. The three-way interaction was significant with a high effect size for the WIM, implying that sediment depth differences for functional diversity are more or less pronounced depending on the station. This is partially reflected in the significant station differences at the WIM (Ar $\times$ WD, Table 3, Fig. 3d).

For the standing stock descriptors, factor interactions were significant at the IM and indicate the variability of the sediment depth effect at different stations, water depths and areas (Table 3; Fig. 3; Supplement, Appendix B, Table B4).

\section{Discussion}

The aim of this study was to analyse and assess the importance of different spatial scales in structuring deep-sea meiofaunal communities. To achieve this, a large set of sediment samples from different submarine canyons along the European margins in the northeast Atlantic, encompassing spatial scales ranging from centimetres to hundreds of kilometres, were analysed for nematode community patterns, using different sets of descriptors to describe community structure, structural diversity, functional diversity and standing stocks. This study is the first to include functional parameters as descriptors of meiofauna communities to reveal the importance 
of different spatial scales and discuss associated processes on deep-sea benthic communities. In support of using nematodes as representative taxon, we note here that they comprise $90 \%$ or more of the metazoan organisms in the deep sea, they exhibit very high species and genus richness, are sensitive to environmental perturbations and have well-established functional traits which have been used successfully in biodiversity and ecosystem functioning studies (Danovaro, 2012).

By using submarine canyons - assumed to be the most heterogeneous environments in the deep marine realm - to test the importance of different spatial scales, we perhaps reduce the possibility that larger scale gradients, such as latitudinal and bathymetrical, attain an important status in driving benthic assemblages because local-scale heterogeneity can be the paramount effect in structuring the resident fauna (Rex et al., 1993, 2006; Rex and Etter, 2010). Yet, considering the pervasiveness of canyons along the world's continental margins (De Leo et al., 2010; Harris and Whiteway, 2011), an important source of heterogeneity may be omitted in studies that exclude canyon ecosystems in assessing spatial-scale importance.

\subsection{Interregional, regional and subregional patterns and processes: differences between margins, water depths and canyon areas}

Latitudinal (interregional and regional scale) and bathymetrical (subregional) gradients in benthic assemblages have been widely recognised in the deep sea (Rex et al., 1993; Rex et al., 2006; Rex and Etter, 2010), including for meiofaunal organisms (Rex et al., 2001; Lambshead et al., 2002; Mokievsky and Azovsky, 2002; Mokievsky et al., 2007). These large geographical gradients may represent environmental gradients or contrasts that drive the faunal assemblages. We noticed clear differences in community structure and structural diversity between the IM and WIM, but we cannot rule out that a small component of the observed variability is due to bathymetric differences, since water-depth comparisons were not the same at each investigated margin. Water depth and latitude (or margin differences) may be inextricably linked because of ocean basin topography, water-mass characteristics, oceanographic currents and fronts, and the role of depth needs to be accounted for when analysing latitudinal patterns to avoid confounding the role of the most important scale (Lambshead et al., 2001; Rex et al., 2001). In doing so, Rex et al. (2001) suggested that nematode patterns are predominantly shaped by bathymetrical changes rather than latitudinal differences when comparing only those two variables. The 3-way PERMANOVA results gave no indication of an overall significant water depth effect, but within each margin, our analyses (4-way PERMANOVA) showed that water depth affected community structure and structural diversity, but not standing stocks, whilst nematode functional diversity only differed with water depth at the IM. The benthic environment at different margins can be typified by dif- ferent euphotic productivity regimes, and consequently variable phytodetrital influx and quality. Water depth differences may add to the gradient created by variable surface production through the degradation processes that ensue; deeper stations may receive more degraded organic matter compared to shallower locations, resulting in benthic structure and diversity differences. The contrast between $700 \mathrm{~m}$ and $1000 \mathrm{~m}$ stations at the IM in terms of phytodetrital influx and presence of organic matter may be greater than is the case when comparing 3400 and $4300 \mathrm{~m}$ depth stations at the WIM, because of the higher down-canyon transport, more rugged topography, and greater accumulation rates in the upper regions of the canyon/channel systems compared to the deeper parts. The nematode functional diversity differences between water depths at the IM, and the lack of them at the WIM, may be representative for such contrasts - nematode functional diversity may have complied with the differences in food arrival. Exacerbating the effect of the here observed water depth contrast between margins could be the underlying regional differences in euphotic production because the locations that are characterised by different water depths are spread geographically and hence include a horizontal spatial component.

The North Atlantic is a particularly productive area with high deep-sea fluxes because of inadequate zooplankton grazing in the upper water column (Longhurst et al., 1995; Longhurst, 2007). This is particularly the case for the Porcupine Abyssal Plain and adjacent margin where the Gollum Channels are situated and further south along the Goban Spur, below which the Whittard Canyon is located (Levin et al., 2001a and references therein). Phytodetrital fluxes to the deep seafloor are much less common at the WIM than at the IM (Levin and Gooday, 2003 and references therein), and different water mass characteristics at each margin may have added to this contrast. The IM locations were characterised by higher temperatures and salinity than the deeper stations at the WIM due to their position within the Mediterranean Outflow Water (Ingels et al., 2011b). Enhanced phytodetrital input and higher temperatures at and above the seabed have been shown to stimulate bacterial growth and densities, consequently adding to the total pool of meiobenthic food resources (Moeseneder et al., 2012; Lochte and Turley, 1988; Boetius et al., 2000) with possibly nematode structural and functional diversity changes as a response. Reduced oxygen availability in areas associated with high production levels and carbon burial, such as reported for Oxygen Minimum Zones worldwide (including canyons, e.g. De Leo et al., 2012), should also be considered at the water depth or subregional scale. Reduced oxygen levels may stimulate meiofauna in such environments because their high tolerance to hypoxia, the abundant food supply and release from predation by the reduced macro- and megafauna (Levin, 2003). Sedimentary organic enrichment as observed in the Whittard Canyon (Duineveld et al., 2001; Ingels et al., 2011b) may even lead to chemotrophic species benefiting from the 
resulting reduced conditions (Ingels et al., 2011b). For the Whittard Canyon and Gollum Channels (IM), the abundance of chemotrophic species (Astomonema southwardorum and Parabostrichus bathyalis) varied substantially with water depth (Ingels et al., 2011b; Tchesunov et al., 2012), possibly explaining the subregional or water depth differences observed for community structure and structural and functional diversity. These differences have likely contributed to the larger water depth effect-sizes observed for the IM compared to the WIM (Fig. 3), since chemotrophic nematode genera are absent from the WIM in the dataset here analysed. Water depth differences may also bear a relation to grain size differences, particularly in canyons where hydrodynamic flow is able to sort sediment particles efficiently along a water depth gradient. Grain size is known to regulate benthic diversity (Etter and Grassle, 1992) beyond the effects of water depth and food input (Leduc et al., 2012). Although the effect size of the water depth factor is limited, significant community descriptor differences between water depth levels suggest the existence of regulating mechanisms on the associated subregional scale, but differences were not clear for standing stock descriptors. The lack of significant standing stock differences at the interregional, regional and subregional scales suggest that biomass and abundance patterns are likely driven by patchiness and processes on smaller spatial scales within each investigated canyon system.

Turning to the regional spatial scale within each margin separately, we have to appreciate the contrasts posed between different canyon areas. It was shown that the canyon communities differed between different margins in terms of community structure and structural diversity, but variability is also high within each margin. Area differences were significant for the community structure and the structural and functional diversity descriptors (Table $3 a, b, c)$, albeit with several significant interactions with water depth and sediment depth, implying levels of variability being expressed differently within factor combinations of factor levels. Submarine canyons are arguably the most heterogeneous habitats in the deep sea, displaying remarkable variability in terms of morphology, topography, sediment transport processes, hydrodynamic activity, geological structure, size, sinuosity, substratum types, position and distance from land and river systems; all characteristics that may be determinative for the type of fauna that resides in canyons. Inter-canyon community structure and structural diversity differences were more pronounced for the WIM than for the IM, even though the Gollum Channels and Whittard Canyon (IM) appear more diverse in terms of geomorphological structure compared to the canyons and slope area at the WIM. The integration of slope samples in the canyon dataset at the WIM, and the fact that not all WIM canyons are connected to river systems may be the reason for the higher effect size attributed to area differences at the WIM. This highlights the importance of intercanyon differences (i.e. regional scale) and processes that act on this scale and their role in regulating benthic commu- nities, which seems superimposed on the effects associated with continental margin and water depth differences.

\subsection{Macro-, meso- and micro-scale patterns and processes: differences between stations, cores and sediment depth layers}

The heterogeneity observed between canyon areas extends to the within-canyon comparison between stations (macroscale, $5-50 \mathrm{~km}$ apart), and between the locations of cores sampled at each station (meso-scale, 1-200 m). Highest effect sizes on community descriptors occurred at the macroand micro-scale, implying that processes that act on the scale of stations and sediment depth layers are determinative for structure, structural and functional diversity, and standing stocks of the resident communities. Differences between cores were minor compared to sediment depth and station differences, suggesting the distances between cores hosted no great faunal variability. Only for the community structure, significant differences were observed between cores, with similar effect sizes as canyon area (regional scale) and water depth (subregional scale) differences. The observed community structure differences between adjacent patches of seafloor at each station suggest that small-scale heterogeneity may be at the basis of niche separation for different genera in this case, with different genera benefiting from different environmental conditions over small (1-200 m) distances. Structural and functional diversity and standing stocks, on the other hand, are more uniform over these distances, and seem more susceptible to differences over $\mathrm{cm}$-scales.

Submarine canyons offer a highly heterogeneous habitat relative to the slopes (Levin and Gooday, 2003), which translates into numerous available subhabitats within these systems (flanks, walls, overhangs, thalweg, sedimented terraces and slopes, etc.). Although this study only investigated sedimented areas within the canyon systems, increased heterogeneity also applies for these subhabitats as indicated by the high station effect sizes. Processes acting on this macroscale, such as hydrodynamic activity and frequency and intensity of sediment disturbance events may be superimposed on the patterns caused by larger spatial scale processes such as regional or water depth-dependent phytodetrital input, and this seems likely the case for submarine canyon systems. Environmental variables such as oxygen, temperature, resource availability, and grain size may vary with within-canyon morphology and associated flow dynamics, including enhanced currents and detrital flows, exerting control on the faunal communities present (Vetter and Dayton, 1999). Topographical effects on the within-canyon scale (macro-scale) have also been observed to drive the quantity and availability of food resources leading to different faunal communities at relatively short distances from each other (McClain and Barry, 2010). The aggregation of organisms at locations with enhanced food availability within a canyon may augment the effects of biotic interactions between different faunal groups 
and species, leading to further fluctuations of community characteristics over small to medium distances (Gallucci et al., 2008a; McClain and Barry, 2010). The within-canyon processes relevant for the meso-scale mentioned here are likely more important than the larger-scale processes in this study judging by the high station variance components, particularly for community structure (Ar $\times$ WD, Fig. 3a).

Community structure exhibits greatest differences between stations, but the sediment depth effect is here considered as the most important factor affecting structural and functional diversity and standing stocks and is likely related to numerous processes, environmental and biological, acting on the $\mathrm{cm}$ - or micro-scale. The micro-scale results presented pertain to the variability observed along the vertical sediment profile, but it is possible that the results bear implications which are not limited to the vertical gradients per se and likely representative for small horizontal variations along the deep-sea floor. This could particularly be the case in canyon environments where heterogeneity on very small spatial scales is high. Environmental gradients on the cmscale are imperative in driving benthic assemblages because they define the suitability of the niches that are exploited by different small-sized benthic taxa, and are influenced by the activities of the taxa themselves (e.g. bioturbation and nutrient flux generation). Previous studies suggest that the spatial dynamics of meiofauna communities are highly localized (e.g. Gallucci et al., 2008b; Fonseca et al., 2010; Guilini et al., 2011), but small-scale patterns of deep-sea meiofauna are still poorly understood (Snelgrove and Smith, 2002). It is believed that like macrofauna organisms, meiofauna species are patchily distributed with patch sizes ranging a few centimetres to meters (Gallucci et al., 2008b) which accords with our results. Nematodes, for instance, are attracted to patches with high levels of food, but the scale on which food input drives nematode communities varies from local-scale patches to regional-scale phytodetrital input. Fonseca et al. (2010) reported that chloroplastic pigments, as an indicator of food availability, may vary most on very small scales $(\mathrm{cm})$, implying that these are the results of local variability. In the same study, however, distance between cores - and not sediment depth - was one of the more important scales. This is possibly related to the distribution patterns of chloroplastic pigment content of the sediments in the Arctic deep sea. However, the authors also suggested that other (unmeasured) environmental variables are likely the main cause of smallscale fauna variability. The contrast between Arctic deep-sea sediments (Fonseca et al., 2010) and the canyon sediments in the present study may explain the difference in importance of vertical scale in driving communities; whilst Arctic deepsea sediments are characterised by a surficial layer of phytodetrital food over larger areas, regulated by strong seasonality, canyon sediments are characterised by different levels of disturbance and temporal dynamics, allowing the burial of organic matter in deeper sediment layers and enhancement of microhabitat variability. The strong heterogeneity on small spatial and short temporal (disturbance-related) scales in canyon sediments may hence add to the contrasting observations.

It is on the micro-scale that also the sediment grain size should be considered as a regulating factor for benthic communities. Particle-size diversity is known to positively influence meiofaunal diversity through increased partitioning of food resources based on particle size, and/or greater habitat heterogeneity (Leduc et al., 2012 and references therein), which would also result in higher functional complexity of the community (Ingels et al., 2009a, 2011b). In the case of canyons, particle size composition can vary greatly between locations because of variable sediment deposition and hydrodynamic sorting. Disturbance events such as gravity flows and slumps add to this variability by redistributing the sediments, as does the feeding and burrowing activity of benthic organisms. These processes cause granulometric differences predominantly on very small scales, and suggest that they are important in regulating benthic patterns along the vertical sediment depth and horizontal $\mathrm{cm}$-scale.

Both food availability and strength and frequency of disturbance events can be considered in the patch mosaic model, whereby the spatio-temporal mosaic of sediment-dwelling communities is driven by highly localised processes, such as colonisation following disturbance events. This supposition is not limited to the meiofauna, macrofauna also exhibits spatial dispersion patterns driven by the presence of a mosaic of microhabitats in canyon sediments (Lamont et al., 1995). Further evidence for this can be found in the association of meiofauna with biogenic structures, such as foraminifera and sponges (Levin et al., 1986; Hasemann and Soltwedel, 2011) which may provide protection against small disturbance events and may indirectly increase food availability, thereby attracting a suite of prokaryotic and metazoan organisms (Levin and Gooday, 1992) or providing a more complex habitat structure (Hasemann and Soltwedel, 2011). In addition, the physically controlled sedimentary environment is modified at the $\mathrm{mm}$ - to $\mathrm{cm}$-scale by bioturbation, both horizontally and vertically, and is a common feature in many canyons.

Considering the biochemistry of sediments, we have to appreciate the role of oxygen and other chemical gradients along the vertical sediment scale, since it has been shown that such variables affect the meiobenthic communities greatly (Vanreusel et al., 1995; Soetaert et al., 1997, 2009; Cook et al., 2000; Gooday et al., 2000; Moodley et al., 2000; Braeckman et al., 2011). Moreover, the interaction between oxygen and food has been found to affect meiofauna assemblages via mechanics explained by the TROX model (Jorissen et al., 1995). In organically enriched canyon sediment patches, the ecosystem is no longer food-controlled, but instead oxygen takes over and drives the structure and diversity of benthic fauna (Jorissen et al., 1995). This is exemplified here at the IM, with higher structural and functional diversity compared to the WIM, partly because of the presence of chemotrophic 
nematode genera in response to reduced micro-patches, and a redox layer appearing closer to the sediment surface (Ingels et al., 2011b). This may be why the role of sediment depth is more important at the IM for different community descriptors (Fig. 3a-d). In recent years, evidence has emerged that oxygen could be a particularly powerful mediator in creating patches (anoxic micro-environments) and/or small-scale reduced environments, in areas that are not truly chemosynthetic (e.g. Van Gaever et al., 2004; Ingels et al., 2011b) with effects on meiobenthic structural and functional diversity as a result.

\section{Conclusions}

The results of the present study suggest that differences between sediment depth layers on a $\mathrm{cm}$-scale are more important than larger spatial scales in regulating benthic patterns. If we are to improve our understanding of these patterns and underlying processes that drive sediment-dwelling faunal communities, their structure, diversity and functioning, we need to focus on the small scales in deep-sea environments, particularly for canyons where heterogeneity is very high. Patchy input and local reworking of phytodetritus and sediments, seafloor microtopography, sediment biogeochemistry as well as benthic biogenic processes in the sediment (e.g. bioturbation, biogeochemical processes mediated by fauna and chemical interactions), and disturbance events, are likely the cause of the high variability observed along the vertical micro-scale in the present study and further investigations into the causal mechanisms are warranted.

\section{Supplementary material related to this article is

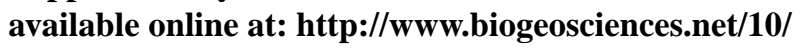 4547/2013/bg-10-4547-2013-supplement.zip.}

Acknowledgements. This research was partly funded by the European HERMES (ECFP6 contract GOCE511234) and HERMIONE projects (EC FP7 Grant no. 26354). JI is currently supported by a Marie Curie Intra-European Fellowship within the 7 th European Commission Framework Programme (Grant Agreement FP7-PEOPLE-2011-IEF no. 00879. For fruitful and constructive discussions, the authors acknowledge Paul Tyler and Craig Smith.

Edited by: R. Danovaro

\section{References}

Anderson, M. J.: PERMANOVA: Permutational multivariate analysis of variance, Department of Statistics, Auckland, 2005.

Anderson, M. J., Gorley, R. N., and Clarke, K. R.: PERMANOVA+ for PRIMER: guide to software and statistical methods, PRIMER-E Ltd, Plymouth, 2008.
Andrassy, I.: The determination of volume and weight of nematodes, Acta Zoologica (Hungarian Academy of Science), 2, 1-15, 1956.

Benedetti-Cecchi, L.: Variability in abundance of algae and invertebrates at different spatial scales on rocky sea shores, Mar. Ecol.Prog. Ser., 215, 79-92, 2001.

Boetius, A., Ferdelman, T., and Lochte, K.: Bacterial activity in sediments of the deep Arabian Sea in relation to vertical flux, DeepSea Res. Pt. I, 47, 28350-2875, 2000.

Bongers, T.: The maturity index: an ecological measure of environmental disturbance based on nematode species composition, Oecologia, 83, 14-19, 1990.

Bongers, T., Alkemade, R., and Yeates, G. W.: Interpretation of disturbance-induced maturity decrease in marine nematode assemblages by means of the maturity index, Mar. Ecol.-Prog. Ser., 76, 135-142, 1991.

Braeckman, U., Provoost, P., Moens, T., Soetaert, K., Middelburg, J. J., Vincx, M., and Vanaverbeke, J.: Biological vs. Physical Mixing Effects on Benthic Food Web Dynamics, Plos One 6, e18078, doi:10.1371/journal.pone.0018078, 2011.

Clarke, K. R. and Gorley, R. N.: PRIMER v6: User manual/tutorial, PRIMER-E, Plymouth, UK, 2006.

Clarke, K. R., Somerfield, P. J., Airoldi, L., and Warwick, R. M.: Exploring interactions by second-stage community analyses, J. Exp. Mar. Biol. Ecol., 338, 179-192, 2006.

Connell, J. H.: Diversity in tropical rain forests and coral reefs high diversity of trees and corals is maintained only in a nonequilibrium state, Science, 199, 1302-1310, 1978.

Cook, A. A., Lambshead, P. J. D., Hawkins, L. E., Mitchell, N., and Levin, L. A.: Nematode abundance at the oxygen minimum zone in the Arabian Sea, Deep-Sea Res. Pt. II, 47, 75-85, 2000.

Cunningham, M. J., Hodgson, S., Masson, D. G., and Parson, L. M.: An evaluation of along- and down-slope sediment transport processes between Goban Spur and Brenot Spur on the Celtic Margin of the Bay of Biscay, Sediment. Geol., 179, 99-116, 2005.

Danovaro, R.: Extending the approaches of biodiversity and ecosystem functioning to the deep ocean, in: Marine Biodiversity and Ecosystem Functioning: Frameworks, methodologies, and integration, edited by: Solan, M., Aspden, R. J., and Paterson, D. M., Oxford University Press, Oxford, 115-126, 2012.

De Leo, F. C., Smith, C. R., Rowden, A. A., Bowden, D. A., and Clark, M. R.: Submarine canyons: hotspots of benthic biomass and productivity in the deep sea, Proc. Roy. Soc. B, 277, 27832792, 2010.

De Leo, F. C., Drazen, J. C., Vetter, E. W., Rowden, A. A., and Smith, C. R.: The effects of submarine canyons and the oxygen minimum zone on deep-sea fish assemblages off Hawaii, DeepSea Res. Pt. I, 64, 54-70, 2012.

de Stigter, H. C., Boer, W., Mendes, P., Jesus, C. C., Thomsen, L., van den Bergh, G. D., and van Weering, T. C. E.: Recent sediment transport and deposition in the Nazare Canyon, Portuguese continental margin, Mar. Geol., 246, 144-164, 2007.

de Stigter, H. C., Jesus, C. C. S., Boer, W., Richter, T. O., Costa, A., and van Weering, T. C. E.: Recent sediment transport and deposition in the Lisbon-Setúbal and Cascais submarine canyons, Portuguese continental margin, Deep-Sea Res. Pt. II, 58, 23212344, 2011.

Deprez, T., Steyaert, M., Vanaverbeke, J., Speybroeck, J., Raes, M., Derycke, S., De Smet, G., Ingels, J., Vanreusel, A., Van Gaever, 
S., and Vincx, M.: NeMys, World Wide Web electronic publication, nemys.ugent.be, Department of Marine Biology, Ghent University, Ghent, 2005.

Duineveld, G., Lavaleye, M., Berghuis, E., and de Wilde, P.: Activity and composition of the benthic fauna in the Whittard Canyon and the adjacent continental slope (NE Atlantic), Oceanol. Acta, 24, 69-83, 2001.

Eckman, J. E. and Thistle, D.: Small-scale spatial pattern in meiobenthos in the San-Diego Trough, Deep-Sea Res. Pt. A, 35, 1565-1578, 1988.

Etter, R. J. and Grassle, J. F.: Patterns of species diversity in the deep sea as a function of sediment particle size diversity, Nature, 360, 576-578, 1992.

Fletcher, D. J. and Underwood, A. J.: How to cope with negative estimates of components of variance in ecological field studies, J. Exp. Mar. Biol. Ecol., 273, 89-95, 2002.

Fonseca, G., Soltwedel, T., Vanreusel, A., and Lindegarth, M.: Variation in nematode assemblages over multiple spatial scales and environmental conditions in Arctic deep seas, Prog. Oceanogr., 84, 174-184, 2010.

Gallucci, F., Fonseca, G., and Soltwedel, T.: Effects of megafauna exclusion on nematode assemblages at a deep-sea site, Deep-Sea Res. Pt. I, 55, 332-349, 2008a.

Gallucci, F., Moens, T., Vanreusel, A., and Fonseca, G.: Active colonisation of disturbed sediments by deep-sea nematodes: evidence for the patch mosaic model, Mar. Ecol.-Prog. Ser., 367, 173-183, 2008b.

Gooday, A. J., Bernhard, J. M., Levin, L. A., and Suhr S. B.: Foraminifera in the Arabian Sea oxygen minimum zone and other oxygen-deficient settings: taxonomic composition, diversity, and relation to metazoan faunas, Deep-Sea Res. Pt. II, 47, 25-54, 2000.

Guilini, K., Soltwedel, T., van Oevelen, D., and Vanreusel, A.: Deep-Sea Nematodes Actively Colonise Sediments, Irrespective of the Presence of a Pulse of Organic Matter: Results from an In-Situ Experiment, Plos One, 6, e18912, doi:10.1371/journal.pone.0018912, 2011.

Harris, P. T. and Whiteway, T.: Global distribution of large submarine canyons: Geomorphic differences between active and passive continental margins, Mar. Geol., 285, 69-86, 2011.

Hasemann, C. and Soltwedel, T.: Small-Scale Heterogeneity in Deep-Sea Nematode Communities around Biogenic Structures, Plos One. 6,, e29152, doi:10.1371/journal.pone.0029152, 2011.

Heip, C., Vincx, M., and Vranken, G.: The Ecology of Marine Nematodes, Oceanogr. Mar. Biol., 23, 399-489, 1985.

Heip, C., Herman, P., and Soetaert, K.: Indices of Diversity and Evenness, Oceanis, 24, 61-87, 1998.

Hill, A. E., Souza, A. J., Jones, K., Simpson, J. H., Shapiro, G. I., McCandliss, R., Wilson, H., and Leftley, J.: The Malin cascade in winter 1996, J. Mar. Res., 56, 87-106, 1998.

Hill, M. O.: Diversity and evenness: a unifying notation and its consequences, Ecology, 54, 427-432, 1973.

Hubbell, S. P.: The unified neutral theory of biodiversity and biogeography Princeton University Press, Princeton, New Jersey, USA, 2001.

Hurlbert, S. H.: The nonconcept of species diversity: a critique and alternative parameters, Ecology, 52, 577-586, 1971.

Huston, M. A.: Local processes and regional patterns: appropriate scales for understanding variation in the diversity of plants and animals, Oikos, 86, 393-401, 1999.

Ingels, J., Van Rooij, D., and Vanreusel, A.:. HERMES RV Belgica 2006/13 Biology cruise report (23-29 June 2006): Gollum Channels and Whittard Canyon, Internal publication, RCMG, Ghent University, 2006.

Ingels, J., Kiriakoulakis, K., Wolff, G. A., and Vanreusel, A.: Nematode diversity and its relation to quantity and quality of sedimentary organic matter in the Nazaré Canyon, Western Iberian Margin, Deep-Sea Res. Pt. I, 56, 1521-1539, 2009 a.

Ingels, J., Billett, D. S. M., Kiriakoulakis, K., Wolff, G. A., and Vanreusel, A.: Structural and functional diversity of Nematoda in relation with environmental variables in the Setúbal and Cascais canyons, Western Iberian Margin, Deep-Sea Res. Pt. II, 58, 2354-2368, 2011a.

Ingels, J., Kiriakoulakis, K., Wolff, G. A., and Vanreusel, A.: Nematode abundance in sediments obtained during RRS Discovery cruise D297. National Oceanography Centre, Southampton, doi:10.1594/PANGAEA.776602, (Dataset), 2009b.

Ingels, J., Billett, D.S.M., Kiriakoulakis, K., Wolff, G.A., and Vanreusel A.: Nematode abundance in sediments obtained during RRS Charles Darwin cruise CD179, National Oceanography Centre, Southampton, doi:10.1594/PANGAEA.776656, (Dataset), 2011d.

Ingels, J., Billett, D. S. M., and Vanreusel, A.: Nematode densities from in situ feeding experiments in the Nazare Canyon conducted with sediments from ROV push-core JC1095-PUC02, Department of Biology, University of Ghent, doi:10.1594/PANGAEA.777030, (Dataset), 2011e.

Ingels, J., Billett, D.S.M., and Vanreusel, A.: Nematode densities from in situ feeding experiments in the Nazare Canyon conducted with sediments from ROV push-core JC1095-PUC03. Department of Biology, University of Ghent, doi:10.1594/PANGAEA.777032, (Dataset), 2011f.

Ingels, J., Billett, D. S. M., and Vanreusel, A.: Nematode densities from in situ feeding experiments in the Nazare Canyon conducted with sediments from ROV push-core JC1095-PUC09. Department of Biology, University of Ghent, doi:10.1594/PANGAEA.777033, (Dataset), 2011g.

Ingels, J., Tchesunov, A., and Vanreusel, A.: Nematode abundance in sediments obtained during the Belgica cruise BG06/13, Gollum Channels and Whittard Canyon. National Oceanography Centre, Southampton, doi:10.1594/PANGAEA.776716, (Dataset), 2011h.

Ingels, J., Tchesunov, A., and Vanreusel, A.: Meiofauna in the Gollum Channels and the Whittard Canyon, Celtic Margin - How local environmental conditions shape nematode structure and function, Plos One, 6, e20094, doi:10.1371/journal.pone.0020094, $2011 \mathrm{~b}$.

Ingels, J., Billett D. S. M., and Vanreusel, A.: An insight into the feeding ecology of deep-sea canyon nematodes - Results from field observations and the first in-situ ${ }^{13} \mathrm{C}$ feeding experiment in the Nazaré Canyon, J. Exp. Mar. Biol. Ecol., 396, 185-193, 2011c.

Ivanov, V. V., Shapiro, G. I., Huthnance, J. M., Aleynik, D. L., and Golovin, P. N.: Cascades of dense water around the world ocean, Prog. Oceanogr., 60, 47-98, 2004.

Jorissen, F. J., de Stigter, H. C., and Widmark, J. G. V.: A conceptual model explaining benthic foraminiferal microhabitats, Mar. Micropaleon., 26, 3-15, 1995. 
Jumars, P. A.: Deep-sea species diversity - Does it have a characteristic scale, J. Mar. Res., 34, 217-246, 1976.

Kiriakoulakis, K., Blackbird, S., Ingels, J., Vanreusel, A., and Wolff, G. A.: Organic geochemistry of submarine canyons: The Portuguese Margin, Deep-Sea Res. Pt. II, 58, 2477-2488, 2011.

Lambshead, P. J. D., Tietjen, J., Moncrieff, C. B., and Ferrero, T. J.: North Atlantic latitudinal diversity patterns in deep-sea marine nematode data: a reply to Rex et al., Mari. Ecol.-Prog. Ser., 210, 299-301, 2001.

Lambshead, P. J. D., Brown, C. J., Ferrero, T. J., Mitchell, N. J., Smith, C. R., Hawkins, L. E., and Tietjen, J.: Latitudinal diversity patterns of deep-sea marine nematodes and organic fluxes: a test from the central equatorial Pacific, Mar. Ecol.-Prog. Ser., 236, 129-135, 2002.

Lamont, P. A., Gage, J. D., and Tyler, P. A.: Deep-sea macrobenthic communities at contrasting sites off Portugal, preliminary results: II spatial dispersion, Internationale Revue Der Gesamten Hydrobiologie, 80, 251-265, 1995.

Lampitt, R. S. and Antia, A. N.: Particle flux in deep seas: regional characteristics and temporal variability, Deep-Sea Res. Pt. I, 44, 1377-1403, 1997.

Lampitt, R. S., Raine, R. C. T., Billett, D. S. M., and Rice, A. L.: Material supply to the European continental slope: A budget based on benthic oxygen demand and organic supply, Deep-Sea Res. Pt. I, 42, 1865-1873, 1995.

Leduc, D., Rowden, A. A., Probert, P. K., Pilditch, C. A., Nodder, S. D., Vanreusel, A., Duineveld, G. C. A., and Witbaard, R.: Further evidence for the effect of particle-size diversity on deep-sea benthic biodiversity, Deep-Sea Res. Pt. I, 63, 164-169, 2012.

Levin, L. A.: Oxygen minimum zone benthos: Adaptation and community response to hypoxia, Oceanogr. Mar. Biol., 41, 1-45, 2003.

Levin, L. A. and Gooday, A. J.: Possible roles for xenophyophores in deep-sea carbon cycling, in: Deep-Sea Food Chains and the Global Carbon Cycle, edited by: Rowe, G. T. and Pariente, V., Kluwer Academic Publishers, the Netherlands, 93-104, 1992.

Levin, L. A. and Gooday, A. J.: The deep Atlantic Ocean, in: Ecosystems of the deep oceans, Ecosystems of the World, edited by: Tyler, P. A., Elsevier, Amsterdam, the Netherlands, 111-178, 2003.

Levin, L. A., Demaster, D. J., McCann, L. D., and Thomas, C. L.: Effects of giant protozoans (Class Xenophyophorea) on deepseamount benthos, Mar. Ecol.-Prog. Ser., 29, 99-104, 1986.

Levin, L. A., Boesch, D. F., Covich, A., Dahm, C., Erseus, C., Ewel, K. C., Kneib, R. T., Moldenke, A., Palmer, M. A., Snelgrove, P., Strayer, D., and Weslawski, J. M.: The function of marine critical transition zones and the importance of sediment biodiversity, Ecosystems, 4, 430-451, 2001a.

Levin, L. A., Etter, R. J., Rex, M. A., Gooday, A. J., Smith, C. R., Pineda, J., Stuart, C. T., Hessler, R. R., and Pawson, D.: Environmental influences on regional deep-sea species diversity, Ann. Rev. Ecol. Syst., 32, 51-93, 2001 b.

Levin, L. A., Sibuet, M., Gooday, A. J., Smith, C. R., and Vanreusel, A.: The roles of habitat heterogeneity in generating and maintaining biodiversity on continental margins: an introduction, Mar. Ecol., 31, 1-5, 2010.

Lochte, K. and Turley, C. M.: Bacteria and cyanobacteria associated with phytodetritus in the deep sea, Nature, 333, 67-69, 1988.
Longhurst, A. R.: Ecological geography of the sea, Academic Press, San Diego, 2007.

Longhurst, A., Sathyendranath, S., Platt, T., and Caverhill, C.: An estimate of global primary production in the ocean from satellite radiometer data, J. Plank. Res., 17, 1245-1271, 1995.

Masson, D. G., Huvenne, V. A. I., de Stigter, H. C., Arzola, R. G., and LeBas, T. P.: Sedimentary processes in the middle Nazaré Canyon, Deep-Sea Res. Pt. II, 58, 2369-2387, 2011.

McClain, C. R. and Barry, J. P.: Habitat heterogeneity, disturbance, and productivity work in concert to regulate biodiversity in deep submarine canyons, Ecology, 91, 964-976, 2010.

McClain, C. R., Stegen, J. C., and Hurlbert, A. H.: Dispersal, environmental niches and oceanic-scale turnover in deep-sea bivalves, Proc. Roy. Soc. B, 279, 1993-2002, doi:10.1098/rspb.2011.2166, 2011.

Moeseneder, M. M., Smith Jr., K. L., Ruhl, H. A., Jones, D. O. B., Witte, U., and Prosser, J. I.: Temporal and depth-related differences in prokaryotic communities in abyssal sediments associated with particulate organic carbon flux, Deep-Sea Res. Pt. I, 70, 26-35, 2012.

Mokievsky, V. and Azovsky, A.: Re-evaluation of species diversity patterns of free-living marine nematodes, Mar. Ecol.-Prog. Ser. 238, 101-108, 2002.

Mokievsky, V. O., Udalov, A. A., and Azovskii, A. I.: Quantitative distribution of meiobenthos in deep-water zones of the World Ocean, Oceanology, 47, 797-813, 2007.

Moodley, L., Chen, G. T., Heip, C., and Vincx, M.: Vertical distribution of meiofauna in sediments from contrasting sites in the Adriatic Sea: Clues to the role of abiotic versus biotic control, Ophelia, 53, 203-212, 2000.

Paterson, D. M., Defew, E. C., and Jabour, J.: Ecosystem Function and co-evolution of terminology in marine science and management, in: Marine Biodiversity and Ecosystem Functioning: Frameworks, methodologies, and integration, edited by: Solan, M., Aspden, R. J., and Paterson, D. M., Oxford Univeristy Press, Oxford, 24-33, 2012.

Platt, H. M. and Warwick, R. M.: Freeliving marine nematodes: part II British chromadorids: pictorial key to world genera and notes for the identification of British species, 1988.

Quaresma, L. S., Vitorino, J., Oliveira, A., and da Silva, J.: Evidence of sediment resuspension by nonlinear internal waves on the western Portuguese mid-shelf, Mar. Geol., 246, 123-143, 2007.

Raffaelli, D. and Friedlander, A. M.: Biodiversity and ecosystem functioning: an ecosystem-level approach, in: Marine Biodiversity and Ecosystem Functioning: Frameworks, methodologies, and integration, edited by: Solan, M., Aspden, R. J., and Paterson, D. M., Oxford University Press, Oxford, 149-163, 2012.

Rex, M. A. and Etter, R. J.: Deep-sea biodiversity: pattern and scale, Harvard University Pr., Harvard, 2010.

Rex, M. A., Stuart, C. T., Hessler, R. R., Allen, J. A., Sanders, H. L., and Wilson, G. D. F.: Global-Scale Latitudinal Patterns of Species-Diversity in the Deep-Sea Benthos, Nature, 365, 636639, 1993.

Rex, M. A., Stuart, C. T., and Etter, R. J.: Do deep-sea nematodes show a positive latitudinal gradient of species diversity?, The potential role of depth, Mar. Ecol.-Prog. Ser., 210, 297-298, 2001.

Rex, M. A., Etter, R. J., Morris, J. S., Crouse, J., McClain, C. R., Johnson, N. A., Stuart, C. T., Deming, J. W., Thies, R., and Avery, 
R.: Global bathymetric patterns of standing stock and body size in the deep-sea benthos, Mar. Ecol.-Prog. Ser., 317, 1-8, 2006.

Russell, B. D., Harley, C. D. G., Wernberg, T., Mieszkowska, N., Widdicombe, S., Hall-Spencer, J. M., and Connell, S. D.: Predicting ecosystem shifts requires new approaches that integrate the effects of climate change across entire systems, Biol. Lett., doi:10.1098/rsbl.2011.0779, 2011.

Sanders, H. L.: Marine benthic diversity: a comparative study, Am. Naturalist, 102, 243-282, 1968

Seinhorst, J. W.: A rapid method for the transfer of nematodes from fixative to unhydrous glycerine, Nematologica, 4, 67-69, 1959.

Shepard, F. P. and Dill, R. F.: Submarine canyons and other sea valleys, Rand McNally, Chicago, 1966.

Snelgrove, P. V. R. and Smith, C. R.: A riot of species in an environmental calm: The paradox of the species-rich deep-sea floor, in: Oceanography and Marine Biology, 40, edited by: Gibson, R. N., Barnes, M., and Atkinson, R. J. A., Taylor \& Francis Ltd, London, 311-342, 2002.

Soetaert, K., Vanaverbeke, J., Heip, C., Herman, P. M. J., Middelburg, J. J., Sandee, A., and Duineveld, G.: Nematode distribution in ocean margin sediments of the Goban Spur (northeast Atlantic) in relation to sediment geochemistry, Deep-Sea Res. Pt. I, 44, 1671-1683, 1997.

Soetaert, K., Muthumbi, A., and Heip, C.: Size and shape of ocean margin nematodes: morphological diversity and depth-related patterns, Mar. Ecol.-Prog. Ser., 242, 179-1793, 2002.

Soetaert, K., Franco, M., Lampadariou, N., Muthumbi, A., Steyaert, M., Vandepitte, L., van den Berghe, E., and Vanaverbeke, J.: Factors affecting nematode biomass, length and width from the shelf to the deep sea, Mar. Ecol.-Prog. Ser., 392, 123-132, 2009.

Svensson, J. R., Lindegarth, M., Siccha, M., Lenz, M., Molis, M., Wahl, M., and Pavia, H.: Maximum species richness at intermediate frequencies of disturbance: consistency among levels of productivity, Ecology, 88, 830-838, 2007.

Tchesunov, A. V., Ingels, J., and Popova, E. V.: Marine freeliving nematodes associated with symbiotic bacteria in deep-sea canyons of north-east Atlantic Ocean, Journal of the Marine Biological Association of the United Kingdom FirstView, 1-15, 2012.

Thiel, H.: Meiobenthos and nanobenthos of the deep sea, in: Deepsea Biol., edited by: Rowe, G. T., Wiley, New York, 167-230, 1983.

Thistle, D.: Harpacticoid dispersion patterns - implications for deep-sea diverity maintenance, J. Mar. Res., 36, 377-397, 1978.
Tyler, P., Amaro, T., Arzola, R., Cunha, M. R., de Stigter, H., Gooday, A., Huvenne, V., Ingels, J., Kiriakoulakis, K., Lastras, G., Masson, D., Oliveira, A., Pattenden, A., Vanreusel, A., Van Weering, T., Vitorino, J., Witte, U., and Wolff, G.: Europe's Grand Canyon Nazare Submarine Canyon, Oceanography, 22, 46-57, 2009.

Van Gaever, S., Vanreusel, A., Hughes, J. A., Bett, B., and Kiriakoulakis, K.: The macro- and micro-scale patchiness of meiobenthos associated with the Darwin Mounds (north-east Atlantic), J. Mar. Biol. Ass. UK, 84, 547-556, 2004.

Vanreusel, A., Vincx, M., Schram, D., and Vangansbeke, D.: On the Vertical-Distribution of the Metazoan Meiofauna in Shelf Break and Upper Slope Habitats of the NE Atlantic, Internationale Revue Der Gesamten Hydrobiologie, 80, 313-326, 1995.

Vanreusel, A., Fonseca, G., Danovaro, R., da Silva, M., Esteves, A., Ferrero, T., Gad, G., Galtsova, V., Gambi, C., Genevois, V., Ingels, J., Ingole, B., Lampadariou, N., Merckx, B., Miljutin, D., Miljutina, M., Muthumbi, A., Netto, S., Portnova, D., Radziejewska, T., Raes, M., Tchesunov, A., Vanaverbeke, J., Van Gaever, S., Venekey, V., Bezerra, T., Flint, H., Copley, J., Pape, E., Zeppilli, D., Martinez, P., and Galeron, J.: The contribution of deep-sea macrohabitat heterogeneity to global nematode diversity, Mar. Ecol. Evolut. Persp., 31, 6-20, 2010.

Vetter, E. W. and Dayton, P. K.: Organic enrichment by macrophyte detritus, and abundance patterns of megafaunal populations in submarine canyons, Mar. Ecol.-Prog. Ser., 186, 137-148, 1999.

Vetter, E. W., Smith, C. R., and De Leo, F. C.: Hawaiian hotspots: enhanced megafaunal abundance and diversity in submarine canyons on the oceanic islands of Hawaii, Mar. Ecol., 31, 183199, 2010.

Vitorino, J., Oliveira, A., Jouanneau, J. M., and Drago, T.: Winter dynamics on the northern Portuguese shelf, Part 1: physical processes, Prog. Oceanogr., 52, 129-153, 2002.

Volkov, I., Banavar, J. R., Hubbell, S. P., and Maritan, A.: Neutral theory and relative species abundance in ecology, Nature, 424, 1035-1037, 2003.

White, M.: HERMES Deliverable 44: Preliminary report on the hydrography of the Porcupine Seabight (WP5 - Canyon systems), 2006.

Wieser, W.: Beziehungen zwischen Mundhöhlengestalt, Ernährungsweise und Vorkommen bei freilebenden marinen Nematoden, Arkiv För Zoologi, 2, 439-484, 1953. 